\title{
Страхування як спосіб гарантування безпеки банківського кредитування
}

\begin{abstract}
Досить актуальною проблемою для банківських установ є пошук методів мінімізачї кредитних ризиків, які були б відносно універсальними, гнучкими та могли застосовуватися до різних кредитних операцій. Сучасна практика мінімізаиії негативного впливу кредитних ризиків зводиться переважно до створення спеціальних резервів і встановлення лімітів для окремих категорій позичальників, щзо не завжди дозволяе досягнути бажаного результату. В статті здійснено дослідження можливості застосування страхування при гарантуванні безпеки банківського кредитування, зокрема як альтернативного інструменту мінімізації кредитних ризиків банку. За такого підходу страхування кредитних ризиків розглядається як комплекс страхових послуг страхової компанї із забезпечення захисту майнових інтересів кредитора щуоо існуючого ризику неповернення або часткового повернення наданого кредиту внаслідок неплатоспроможності позичальника. Страхування кредитних ризиків враховує страхування непогашення кредиту, страхування відповідальності позичальника за неповернення кредиту та страхування предмета застави. Перевагами використання страхування кредитних ризиків для банку є можливість застосування иьього інструменту до будь-яких позичальників з урахуванням особливостей кредитної угоди, стану платоспроможності позичальника, умов повернення кредиту тощо, а також відносно невеликі витрати, пов'язані зі страхуванням кредитів. За умови страхування кредитних ризиків у банків зникає необхідність формування додаткових резервів під певні кредитні угоди та іммобілізачії частини фінансових ресурсів, щзо сприяє забезпеченню стабільності поточної роботи з обслуговування клієнтів як за активними, так $i$ за пасивними операціями банку. Крім того, при страхуванні кредитних ризиків страхова компанія є додатковим гарантом стабільності функиіонування банку, його можливістю вчасного повернення коштів.
\end{abstract}

Ключові слова: банк; кредитний ризик; страхування кредитних ризиків; страхування відповідальності; страхова премія; страховий випадок; неплатоспроможність позичальника.

Постановка проблеми у загальному вигляді та ії зв'язок $з$ важливими практичними завданнями. Операційна діяльність банківських установ пов'язана 3 протистоянням дії багатьох ризиків, основними 3 яких $\epsilon$ фінансові. Найбільшої уваги банків заслуговують кредитні ризики, адже переважна більшість операцій здійснюється 3 використанням залучених коштів. Стабільна діяльність комерційного банку залежить від наявності достатніх коштів для проведення поточного обслуговування клієнтів, здійснення валютних операцій та операцій з цінними паперами, розміщення депозитів фізичних осіб та інвестування тимчасово вільних коштів юридичних осіб, кредитування реального сектору економіки та надання споживчих кредитів. Мінімізація фінансових ризиків є гарантією майбутньої діяльності фінансової установи. Серед існуючих на сьогодні методів мінімізації кредитних ризиків найбільш поширеним є створення резервів для гарантування надійності власних зобов'язань фінансової установи. Проте цей метод, по перше, не завжди гарантує досягнення бажаного результату, а по-друге, передбачає відволікання й іммобілізацію значної частини коштів банку. Зазначені обставини зумовлюють необхідність пошуку нових підходів до управління та мінімізації кредитних ризиків банку. Одним з напрямів $є$ використання послуг колекторських компаній при мінімізації обсягів проблемної та безнадійної заборгованості. Втім, навіть створення власних колекторських підрозділів не вирішує проблем заборгованості у повному обсязі внаслідок відсутності врегулювання цього питання на законодавчому рівні. Відсутність в Україні закону про колекторську діяльність зобов’язує колекторські фірми та банківські установи користуватися нормами значної кількості правових актів, як іноді суперечать одна одній. Отже існує реальна потреба в наявності зовнішнього, відокремленого від самого комерційного банку, гаранта фінансової стабільності. Таку функцію можуть взяти на себе й інші учасники фінансового ринку - страхові компанії. У відносинах «страхова компанія - банк» існує кілька сценаріїв взаємодії, зокрема предметом договору може бути відповідальність позичальника, майно, що є заставою при кредитуванні тощо. Використання страхування допоможе банкам зменшити збитки від кредитних ризиків, у випадках визнання заборгованості безнадійною або відмови позичальника сплачувати відсотки. Наявність альтернативних способів мінімізації кредитних ризиків сприятимуть підвищенню стабільності роботи банку, збереженню високого рівня ліквідності та спроможності повноцінного виконання поточних фінансових операцій клієнтів.

Аналіз останніх досліджень і публікацій. Вагомий внесок у дослідження питань, пов'язаних із дослідженням проблем страхування кредитних ризиків, сучасних тенденцій розвитку кредитного страхування в Україні та розвитку інфраструктури вітчизняного ринку кредитного страхування, зробили вітчизняні вченіекономісти, зокрема слід виокремити праці М.С. Клапківа [1], С.В. Волосович [2], I.М. Пріхно [3], І.Г. Пахомової [4], О.А. Шаповала [5], О.В. Швець [6] та ін. 
Високо оцінюючи науковий доробок вказаних науковців, причини виникнення кредитних ризиків, особливо у банківській сфері, і методи їх мінімізації в контексті забезпечення безпеки діяльності банків не можна вважати повністю вивченими і дослідженими. Найбільше уваги варто приділити проблемам активізації страхування у практиці банківського кредитування, а також проблемам, що виникають під час страхування кредитних ризиків, до яких можна вахувати як зростання обсягів простроченої заборгованості позичальників, несвоєчасності виконання обов'язків за кредитними договорами, випадків кредитного шахрайства, так i недосконалість самих кредитних договорів.

Метою роботи $\epsilon$ оцінка можливості застосування страхування як інструменту управління кредитними ризиками комерційного банку та забезпечення більш високого рівня безпеки банківського кредитування.

Викладення основного матеріалу. Одним із найбільш поширених ризиків у фінансово-господарській діяльності банків є кредитний ризик, пов'язаний із можливістю невиконання позичальником своїх фінансових зобов'язань перед банком, іншими кредиторами чи інвесторами у результаті виникнення ризику неплатежу або його неплатоспроможності, який формується у процесі кредитування. Оскільки розвиток кредитних відносин у ринкових умовах (конкуренції, нестійкої кон'юнктури і політичної ситуації) спричинив формування різних систем запобіжних заходів, більш детального розгляду потребують особливості страхування кредитних ризиків.

Про єдність підходів до страхування кредитів у зарубіжній практиці йдеться у дослідженні [7]. Зокрема у польському законодавстві страхування наданих кредитів виокремлено у страхуванні майна в самостійний вид. А російські та німецькі Закони зараховують страхування неповернення кредитів до страхування відповідальності. Вітчизняне законодавство - страхування кредитів (у тому числі відповідальність за непогашення кредитів) до видів добровільного страхування (ст. 6 ЗУ «Про страхування» [8]).

Страхування кредитних ризиків в цілому розглядається як комплекс страхових послуг, які забезпечують страховий захист майнових інтересів кредиторів, пов'язаних з існуванням ризику неповернення кредиту внаслідок неплатоспроможності позичальника. Страхування кредитних ризиків передбачає відшкодування страховою компанією кредитору коштів у разі невиконання позичальником зобов'язань за кредитом. Тобто, страхування кредитних ризиків спрямоване на захист інтересів кредитора в ситуаціях неплатоспроможності позичальника або неповернення ним боргу з інших причин. Практика страхування кредитів в Україні має в основному три форми: страхування ризику непогашення кредиту; страхування позичальником відповідальності за неповернення кредиту; страхування позичальником предмета застави.

За першої форми банк після укладення кредитного договору може самостійно застрахувати наданий кредит, підписавши зі страховою компанією договір про добровільне страхування його непогашення. У такому випадку сума страхових внесків враховується при встановленні ставки позикового процента. Ініціаторами таких страхових операцій мають бути банки, які шукають захисту від кредитного ризику.

Під час звернення до такої форми забезпечення кредиту, банк має переконатися у спроможності страхової компанії виконати свої зобов'язання при настанні страхового випадку.

Проте ця форма ще не одержала належного розвитку. Це можна пояснити такими причинами:

- комерційні банки не можуть сьогодні широко використовувати страхування кредитів, оскільки мають цілком обгрунтовані сумніви щодо надійності та платоспроможності страхових компаній, хоча $є$ щорічне обов’язкове оприлюднення фінансової звітності страховиків;

- порівняно високі страхові премії, яких вимагають страхові компанії, що зумовлює збільшення витрат за рахунок страхових платежів, це спричиняє підвищення цін на товари й послуги;

- банки, намагаючись мінімізувати витрати, прагнуть страхувати кредити з найбільшим ризиком, що стає менш вигідним для страховиків, через необхідність у майбутньому відшкодовувати збитки при настанні страхового випадку;

- у зв'язку з тим, що деякі позичальники вважають страхування своєї відповідальності зайвим витрачанням коштів, нерідкими є випадки відмови від страхування.

Через існування для банків ризику дострокового розірвання договору страхування відповідальності позичальника у будь-який час, але не пізніше 30 днів до завершення дії договору добровільного страхування відповідальності позичальника (відповідно до п. 3 ст. 997 Цивільного кодексу України [9]), доцільним $є$ врахування в умови кредитного договору положення про те, що у разі невиконання позичальником зобов'язань щодо страхування понад 30 календарних днів, кредитор (банк) має право прийняти рішення про підвищення розміру відсоткової ставки за цим кредитом до рівня, який діяв на час укладання кредитної угоди за аналогічними кредитними угодами без договору страхування. Крім того, банк може вимагати дострокового розірвання кредитної угоди і повернення суми боргу з відсотками, що лишилося сплатити позичальнику, за фактичний строк кредитування. Водночас банк має повідомити про це у письмовій формі і встановити розумний період повернення кредиту, який не може бути меншим за 30 календарних днів 3 моменту направлення повідомлення такому позичальнику. Також не виключається можливість для банку розірвання угоди з позичальником у судовому порядку (з ініціативи кредитора).

Отже, страхування кредитних ризиків передбачає страхування кредитів та відповідальності позичальника за непогашення позичених коштів (табл. 1). 
Основні складові добровільного страхування кредитів і відповідальності позичальника за непогашення кредиту

\begin{tabular}{|c|c|c|c|}
\hline $\begin{array}{l}\text { № } \\
\text { 3/ח }\end{array}$ & $\begin{array}{c}\text { Ознака } \\
\text { страхування }\end{array}$ & Страхування кредиту (-ів) & $\begin{array}{r}\text { Страхування відповідальн } \\
\text { позичальника за непогашення } \\
\end{array}$ \\
\hline 1. & Суб’єкт & $\begin{array}{|lllr|}\text { Страхувальником } & \text { кредитор } & \text { (банк) } & \text { або } \\
\text { узгджена з ним третя особа, яка може зазнати } \\
\text { збитків у результаті } & \text { настання } & \text { страхового } \\
\text { випадку, при цьому } & \text { призначення } \\
\text { вигодонабувача є обов’язковим } & \\
\end{array}$ & $\begin{array}{l}\text { Страхувальником } е \text { позичальник, a } \\
\text { вигодонабувачем призначається кредитор або інша } \\
\text { вказана ним особа, яка може зазнати збитків у } \\
\text { результаті настання страхового випадку }\end{array}$ \\
\hline 2. & Об'єкт & $\begin{array}{llrr}\text { Майнові інтереси страхувальника пов'язані зі } \\
\text { збитками, які завдані } & \text { страхувальнику } \\
\text { внаслідок } & \text { невиконання } & \text { (неналежного } \\
\text { виконання) } & \text { позичальником } & \text { (-ми) } & \text { своїх } \\
\text { обов’язків } & \text { щодо своєчасного, повного } \\
\text { повернення позикових коштів } & \text { і відсотків за } \\
\text { користування ними }\end{array}$ & \begin{tabular}{l} 
Майнові інтереси, що не суперечать законодавству \\
України, пов'язані із відшкодуванням \\
страхувальником заподіяної ним шкоди у зв'язку із \\
повним або частковим непогашенням коштів, \\
отриманих у вигляді кредиту \\
\multicolumn{4}{l}{} \\
\end{tabular} \\
\hline 3. & $\begin{array}{l}\text { Страховий } \\
\text { ризик }\end{array}$ & 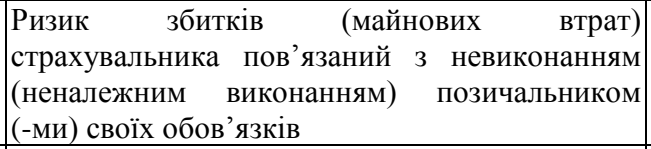 & $\begin{array}{l}\text { Ризик відповідальності, пов'язаної } \\
\text { відшкодуванням страхувальником заподіяної ним } \\
\text { шкоди кредитору, обумовленої } \\
\text { (неналежним виконанням) своїх обов’язків }\end{array}$ \\
\hline 4. & $\begin{array}{l}\text { Страховий } \\
\text { випадок }\end{array}$ & 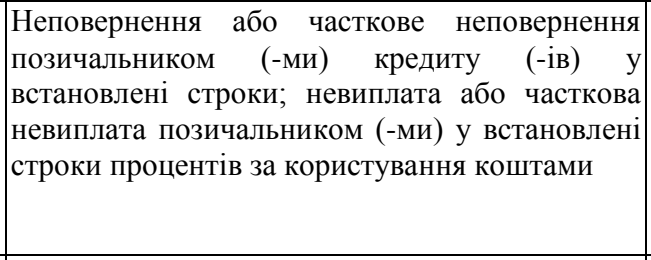 & $\begin{array}{l}\text { Неповернення або часткове неповернення } \\
\text { страхувальником кредиту у встановлені строки; } \\
\text { невиплата або часткова невиплата страхувальником } \\
\text { у встановлені строки процентів за користування } \\
\text { коштами. Договір страхування може передбачати } \\
\text { встановлення мінімальної кількості прострочених } \\
\text { платежів для визначення страхового випадку }\end{array}$ \\
\hline 5 . & $\begin{array}{l}\text { Страхова } \\
\text { сума }\end{array}$ & $\begin{array}{l}\text { люється у межах суми кредиту (-ів) та } \\
\text { в за користування кредитом }\end{array}$ & $\begin{array}{l}\text { Встановлюється у межах суми кредиту та відсотків } \\
\text { за користування кредитом }\end{array}$ \\
\hline 6. & $\begin{array}{c}\text { Період } \\
\text { страхування }\end{array}$ & $\begin{array}{|lrrr|}\text { Визначається на } & \text { період дії } & \text { кредитного } \\
\text { договору або } & \text { кредитних } & \text { договорів } \\
\text { (генеральний договір страхування). } & \\
\end{array}$ & Визначається на період дії кредитного договору \\
\hline 7. & $\mathrm{~T}$ & $\begin{array}{l}\text { Ставка страхового внеску з одиниці страхової } \\
\text { суми за визначений період страхування }\end{array}$ & $\begin{array}{l}\text { Ставка страхового внеску з одиниці страхової суми } \\
\text { за визначений період страхування }\end{array}$ \\
\hline 8. & $\begin{array}{c}\text { Виплата } \\
\text { страхового } \\
\text { відшкодування }\end{array}$ & 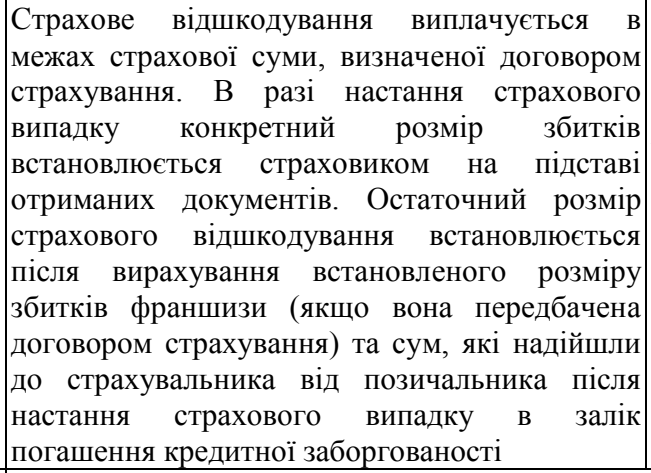 & $\begin{array}{l}\text { Страхове відшкодування виплачується в межах } \\
\text { страхової суми, визначеної договором страхування. } \\
\text { В разі настання страхового випадку конкретний } \\
\text { розмір збитків встановлюється страховиком на } \\
\text { підставі отриманих документів. Остаточний розмір } \\
\text { страхового відшкодування встановлюєтья після } \\
\text { вирахування встановленого розміру збитків } \\
\text { франшизи (якщо вона передбачена договором } \\
\text { страхування) та сум, які надійшли до } \\
\text { вигодонабувача від страхувальника після настання } \\
\text { страхового випадку в залік погашення кредитної } \\
\text { заборгованості }\end{array}$ \\
\hline 9. & $\begin{array}{l}\text { Причини } \\
\text { відмови у } \\
\text { страховій } \\
\text { виплаті }\end{array}$ & $\begin{array}{l}\text { Навмисні дії страхувальника або особи, на ко] } \\
\text { страхувальником або іншою особою, на кори } \\
\text { злочину, що призвів до страхового випадку; пс } \\
\text { неправдивих відомостей або документів, щ } \\
\text { встановлення причин і обставин страхового в } \\
\text { настання страхового випадку або створення пе } \\
\text { збитків }\end{array}$ & $\begin{array}{l}\text { ристь якої укладено договір страхування; вчинення } \\
\text { исть якої укладено договір страхування, умисного } \\
\text { Іодання страхувальником (вигодонабувачем) свідомс } \\
\text { цо впливають на оцінку ризику і об’єктивність } \\
\text { випадку; несвоєчасне повідомлення страховика прс } \\
\text { ерешкод у визначенні обставин, характеру і розміру }\end{array}$ \\
\hline
\end{tabular}

Кожна складова страхування кредитних ризиків має свої особливості. Так суб’єктом страхування при страхуванні кредитів є банк, який уклав зі страховиком договір страхування кредиту, та який у встановленому законодавством України порядку здійснює кредитування на умовах, встановлених кредитним договором. Під час страхування відповідальності за непогашення кредиту суб’єктом страхування $є$ позичальник.

Об’єктом страхування при страхуванні кредитів є майнові інтереси, пов'язані з матеріальними збитками, завданими банку внаслідок невиконання (або неналежного виконання) позичальником своїх обов'язків, передбачених кредитним договором між позичальником та кредитором. Об'єктом страхування при страхуванні відповідальності за непогашення кредиту є відповідальність боржника перед кредитором (банком), який видав кошти в кредит, за погашення кредиту. 
Страховим ризиком в обох випадках є неповернення кредитів банку, що пов'язане 3 невиконанням (неналежним виконанням) позичальником своїх обов'язків, передбачених кредитним договором між позичальником та кредитором. Страхування кредитів реалізовується у формі делькредерного і заставного страхування (рис. 1).

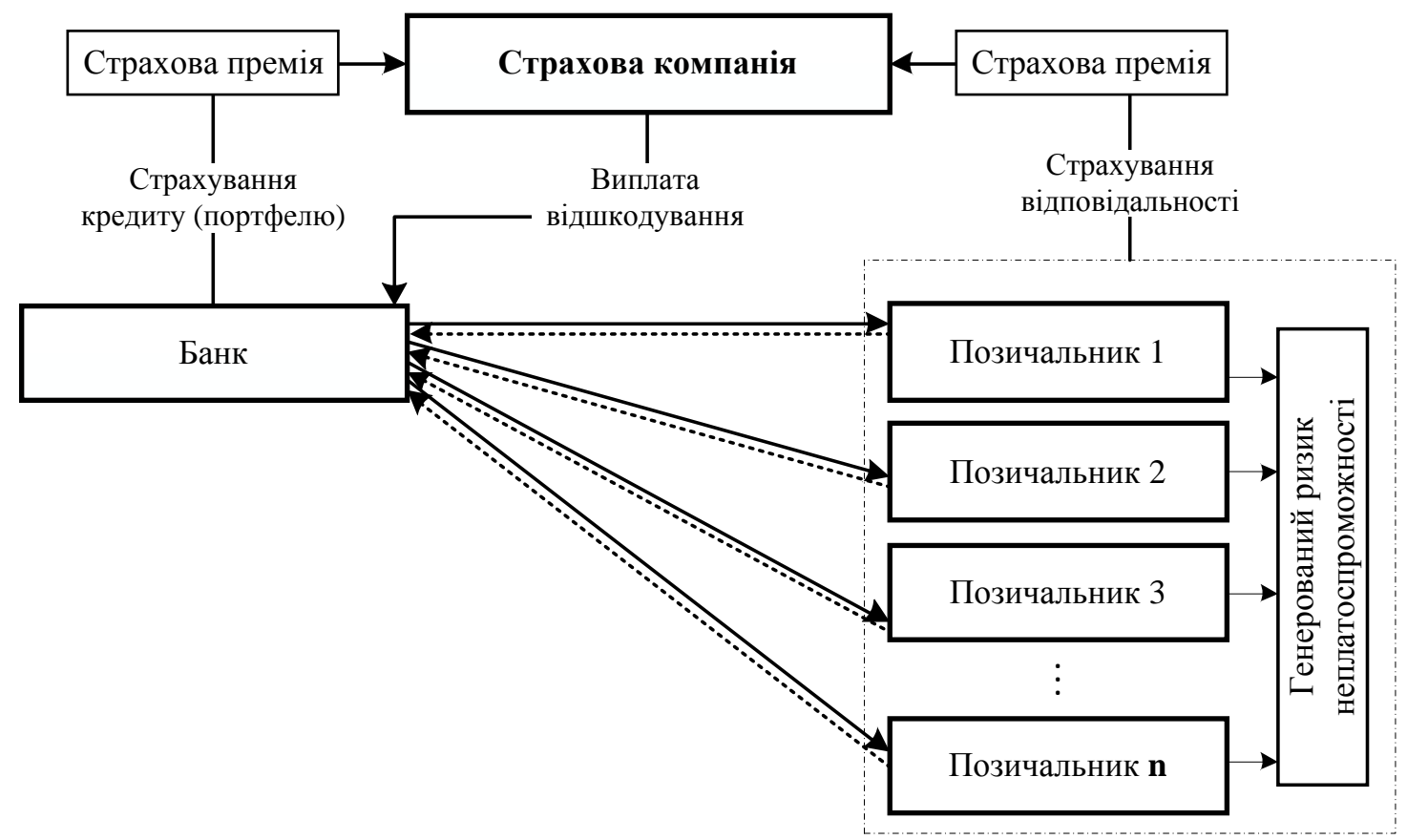

Рис. 1. Схема делькредерного і заставного страхування кредитів (удосконалено авторами на основі [13])

Що стосується управління ризиком кредитного портфеля, то страхування ризику відбувається тільки у формі делькредерного страхування. У цьому випадку страхувальником є банк, а об'єктом страхування відповідальність усіх або окремих позичальників перед банком за своєчасне і повне погашення кредиту i процентів за ним, тобто фінансовий ризик банку одержати збитки внаслідок невиконання або неналежного виконання позичальниками умов кредитних угод. Страхова сума при страхуванні кредитних ризиків встановлюється у межах суми кредиту та відсотків за користування кредитом. Термін страхування в обох випадках визначається на період дії кредитного договору.

Страховий тариф при страхуванні кредитів встановлюється залежно від страхової суми, терміну страхування, а також залежно від конкретних умов договору страхування та ступеня ризику. При страхуванні відповідальності за непогашення кредиту страховий тариф визначається з урахуванням характеру діяльності позичальника, виду його діяльності, особливостей договору, що страхується, наявності заставного майна позичальника та інших суттєвих факторів у кожному конкретному випадку.

Базові річні тарифи з добровільного страхування кредитів, враховуючи відповідальність позичальника за непогашення кредиту, наведено у таблиці 2.

Базові річні страхові тарифи з добровільного страхування кредитів

Таблиия 2

\begin{tabular}{|l|c|}
\hline \multicolumn{1}{|c|}{ Ризики } & $\begin{array}{c}\text { Страховий тариф } \\
\text { (у \% до страхової суми) }\end{array}$ \\
\hline $\begin{array}{l}\text { Ризик збитків (майнових втрат) страхувальника, пов'язаний з невиконанням (неналежним } \\
\text { виконанням) позичальником своїх обов'язків, передбачених кредитним договором між } \\
\text { позичальником та страхувальником (кредитором) }\end{array}$ & 3 \\
\hline $\begin{array}{l}\text { Ризик відповідальності, пов'язаної з відшкодуванням страхувальником заподіяної ним } \\
\text { шкоди третім особам (кредиторам), пов'язаної з невиконанням (неналежним виконанням) } \\
\text { страхувальником (позичальником) своїх обов'язків, передбачених кредитним договором } \\
\text { між страхувальником (позичальником) та третіми особами (кредиторами) }\end{array}$ & 3,5 \\
\hline
\end{tabular}

Джерело: складено авторами на основі $[14,15]$

Страховик при визначенні розміру страхової премії має право застосовувати підвищуючі чи понижуючі коефіцієнти до базових страхових тарифів, що впливають на рівень ризику. Допускається використання таких корегуючих коефіцієнтів (табл. 3). 
Коефіцієнти корегування базового річного страхового тарифу

\begin{tabular}{|c|c|}
\hline Умови & Діапазон значень коефіцієнта \\
\hline Фінансовий стан і особливості діяльності позичальника & $0,1-10$ \\
\hline Умови кредитування & $0,5-3,0$ \\
\hline Умови страхування & $0,05-10$ \\
\hline Умови прийому ризиків на страхування & $0,5-2,0$ \\
\hline
\end{tabular}

Джерело: складено авторами на основі $[14,15]$

Страхова премія (грошова сума, що iï сплачує особа, яка укладає угоду страхування і яка являє собою своєрідну плату за ризик) 3 урахуванням понижуючого коефіцієнта для базового страхового тарифу i корегування за франшизою та витратами на ведення справи обчислюється за формулою:

$$
\Pi_{p}=\mathrm{C}_{\mathrm{C}} \cdot \frac{\mathrm{T}_{\mathrm{C}}}{100 \%} \cdot \mathrm{K}_{\Pi} \cdot\left(1+\frac{\mathrm{B}_{\mathrm{BC}}}{100 \%}\right) \cdot \mathrm{K}_{\Phi},
$$

де $\Pi_{p}-$ річна страхова премія, грн;

$\mathrm{C}_{\mathrm{C}}$ - страхова сума, грн;

$\mathrm{T}_{\mathrm{C}}$ - базова страхова тарифна ставка, \%;

$\mathrm{K}_{\Pi}-$ понижуючий коефіцієнт;

$\mathrm{B}_{\mathrm{BC}}-$ витрати на ведення справи, \%;

$\kappa_{\Phi}-$ коефіцієнт коригування за франшизою (табл. 4).

Таблиия 4

Корегування тарифу за франшизою

\begin{tabular}{|c|c|}
\hline Франшиза (\% від страхової суми) & Коефіцієнт \\
\hline $0-0,1$ & 1,15 \\
\hline $0,1-0,5$ & 1,00 \\
\hline $0,5-1,0$ & 0,95 \\
\hline $1,0-3,0$ & 0,90 \\
\hline 3,0 та більше & 0,85 \\
\hline
\end{tabular}

Джерело: складено авторами на основі $[14,15]$

При укладанні договору страхування на строк менше одного року розрахунок страхової премії здійснюється за формулою:

$$
\Pi_{k}=\Pi_{p} \cdot k
$$

де $\Pi_{k}-$ страхова премія за короткостроковим договором страхування, грн;

$\Pi_{p}$ - річна страхова премія, грн;

$k$ - коефіцієнт короткостроковості (табл. 5).

Показник коефіцієнта короткостроковості від річного страхового тарифу

Таблиияя 5

\begin{tabular}{|c|c|c|c|c|c|c|c|c|c|c|c|c|}
\hline $\begin{array}{c}\text { Строк } \\
\text { страхування, міс. }\end{array}$ & 1 & 2 & 3 & 4 & 5 & 6 & 7 & 8 & 9 & 10 & 11 & 12 \\
\hline$k$ & 0,2 & 0,35 & 0,5 & 0,6 & 0,65 & 0,7 & 0,75 & 0,8 & 0,85 & 0,9 & 0,95 & 1,0 \\
\hline
\end{tabular}

Джерело: складено авторами на основі $[14,15]$

Норматив витрат на ведення справи встановлюється в розмірі до $40 \%$ від суми страхових внесків та визначається в договорі страхування, але в будь-якому разі не більше 40 \% від суми страхових внесків.

Отже, страхування кредитів зводиться до відшкодування фінансовій установі коштів, недоотриманих від позичальників. Дія механізму страхування кредитів банку ілюструється таким прикладом. Позичальник «А» взяв два кредити на суму 130000 грн на рік і 180000 грн на рік і два місяці, відсоткова ставка - 20 \% річних. Позичальником, за згодою з банком, було прийнято рішення погасити борг одним платежем через рік. Встановлена базова страхова тарифна ставка - 3,0 \%. Враховуючи стійкий фінансовий стан позичальника, страховиком прийнято рішення про застосування понижуючого коефіцієнта 0,8. Позичальник «Б» взяв кредит у сумі 800000 грн на 7 місяців. Відсоткова ставка - $22 \%$ річних. Встановлена базова страхова тарифна ставка 3,0 \%. Ліміт відповідальності страховика - 70\%. Витрати на ведення справи в обох випадках - $20 \%$. Після закінчення терміну кредитування, позичальник «Б» не погасив кредит банку.

Для позичальника «А» розмір разового платежу через рік буде становити:

$$
\left(\frac{130000}{(1+0,2)^{1}}+\frac{180000}{(1+0,2)^{1 \frac{1}{6}}}\right) \cdot(1+0,2)^{1}=304612,60 \text { грн. }
$$


Тобто через зміни умов погашення боргу позичальник заплатить банку замість 310000 грн (два платежі) 304612,60 грн (один платіж).

Страхова сума за кредитом позичальника «А» становитиме 304 612,6 грн. Страхова премія страховика для кредиту позичальника «А», обчислена за формулою (1) буде становити:

$$
304612,60 \cdot 0,03 \cdot 0,8 \cdot 1,2 \cdot 1,15=10088,77 \text { грн. }
$$

Для позичальника «Б» розмір платежу за кредитом через 7 місяців буде становити:

$$
800000 \cdot\left(1+0,22 \cdot \frac{7}{12}\right)=902666,67 \text { грн. }
$$

Страхова сума за кредитом позичальника «Б» з урахуванням ліміту відповідальності страховика буде становити:

$$
902666,67 \cdot 0,7=631866,67 \text { грн. }
$$

Страхова премія, з урахуванням коефіцієнта короткостроковості для базового страхового тарифу i корегування за франшизою 0 \%, обчислена за формулою (1) і скорегована за формулою (2) буде складати:

$$
\begin{gathered}
631866,67 \cdot 0,03 \cdot 1,2 \cdot 1,15=26159,28 \text { грн. } \\
26159,28 \cdot 0,75=19619,46 \text { грн. }
\end{gathered}
$$

Враховуючи той факт, що позичальник «Б» не здійснював платежів 3 погашення боргу на користь банку до настання страхового випадку, то банк має право претендувати на виплату страховою компанією компенсації збитків у розмірі всієї страхової суми - 631866,67 грн.

Таким чином, витрати банку, пов'язані зі страхуванням кредитних ризиків, становитимуть 29708,23 грн, тобто сплачені страховій компанії премії за страхуванням кредитів позичальників «А» і «Б».

За відсутності страхування кредитних ризиків у страховій компанії збитки банку будуть складати 902 666,67 грн, а при страхуванні кредиту - 270 800,00 грн.

В цілому при страхуванні кредитних ризиків виплата страхового відшкодування проводиться на підставі пакета документів: договору страхування; кредитного договору; копій листування між страхувальником та позичальником, що стосується цього страхового випадку (якщо таке листування має місце); підтвердження суми заборгованості позичальника перед банком відповідно до даних позичкового рахунку позичальника; паспорта й довідки про присвоєння ідентифікаційного номера позичальника; інших документів, наявність яких, на погляд страхувальника, дає змогу встановити розмір страхового відшкодування за конкретним кредитним договором.

Висновки та перспективи подальших досліджень. На сьогодні слід констатувати наявність багатьох факторів, що генерують кредитні ризики, особливо у банківській діяльності. Необхідність забезпечення стабільності функціонування банківського сектору, а через нього - фінансової системи держави обумовлює актуальність пошуку механізмів та методів мінімізації кредитних ризиків комерційних банків. Досить інноваційним для нашої країни може бути підхід, за якого забезпечується взаємодія двох учасників фінансового ринку - банків та страхових компаній. Під час виконання кожним учасником своїх специфічних функцій досягається зростання безпеки не тільки банківського кредитування, а й стабільності фінансового сектору в цілому. Проведені розрахунки свідчать про доцільність використання страхування кредитних ризиків банками, що сприяє зменшенню збитковості їх роботи. Проте подальшого дослідження потребує практика страхування кредитів у зарубіжних країнах та можливість імплементації їх позитивного досвіду для забезпечення стабільності банківського сектору України.

\section{Список використаної літератури:}

1. Клапків М.С. Страхування фінансових ризиків : монографія / М.С. Клапків. - Тернопіль, 2002. - 570 с.

2. Волосович C. Розвиток інфраструктури ринку кредитного страхування в Україні / С.Волосович // Вісник КНТЕУ. 2011. - № 5. - C. 36-43.

3. Пріхно I.M. Сучасні тенденції розвитку кредитного страхування в Україні / I.M. Пріхно // Вісник Східноєвропейського університету економіки і менеджменту. - 2015. - Вип. 2 (19). - С. 153-161.

4. Пахомова І.Г. Оцінка ринку страхування кредитних ризиків в Україні / I.Г. Пахомова // Ефективна економіка. 2017. - № 6. [Електронний ресурс]. - Режим доступу : http://www.economy.nayka.com.ua/?op=1\&z=5635.

5. Шаповал О.А. Управління ризиками банківського споживчого кредитування : дис. ... к.е.н.: 08.00 .08 / O.А. Шаповал. - Київ : КНТЕУ, 2017. - 261 с. [Електронний ресурс]. - Режим доступу : https://knute.edu.ua.

6. Швець О.В. Контроль та способи мінімізації кредитного ризику банку : дис. ... к.е.н.: 08.00 .08 / О.В. Швець // ДВНЗ «Університет банківської справи». - Київ, 2017. - 211 с. [Електронний ресурс]. - Режим доступу : http://ubs.edu.ua/images/PDF/shvetsdiser.pdf.

7. Полєжаєва С. Необхідність страхування кредитних ризиків для банків / С.Полєжаєва // Ринок цінних паперів України. - 2015. - № 1-2. - С. 119-124.

8. Про страхування : Закон Україн від 07.03.1996 № 85/96-ВР / Верховна Рада України [Електронний ресурс]. Режим доступу : https://zakon.rada.gov.ua/laws/show/85/96-вp/print.

9. Цивільний кодекс України : Кодекс від 16.01.2003 № 435-VI / Верховна Рада України [Електронний ресурс]. Режим доступу : https://zakon.rada.gov.ua/laws/show/435-15. 
10. Примостка Л.О. Фінансовий менеджмент у банку : навч. посібник / Л.О. Примостка. - Київ : КНЕУ, 2009. - 280 с.

11. Нові вектори розвитку страхового ринку України : монографія / кер. авт. кол. д.е.н., проф. О.В. Козьменко. - Суми, 2012. $-316 \mathrm{c}$.

12. Алиев Б.Х. Страхование: учебник / Б.Х. Алиев. - Москва, 2011. -415 с.

13. Євроінтеграційні аспекти розвитку ринків фінансових послуг : монографія / за заг. ред. д.е.н., проф. Н.М. Внукової.Харків, 2018. - 178 с.

14. Правила добровільного страхування кредитів (в тому числі відповідальність позичальника за непогашення кредиту) / СК «АСКА» [Електронний ресурс]. - Режим доступу : https://aska.ua/assets/files/pravila-dobrovilnogostrahuvannya-kreditiv-v-tomu-chisli-vidpovidalnist-pozichalnika-za-nepogashennya-kreditu-nova-redakciya.pdf.

15. Правила добровільного страхування кредитів (в тому числі відповідальність позичальника за непогашення кредиту) / СК «Арсенал-Днепр» [Електронний ресурс]. - Режим доступу : https://arsenal-ic.ua/uploads/0/1040.pdf.

\section{References:}

1. Klapkiv, M.S. (2002), Strahuvannja finansovyh ryzykiv, monografija, Ternopil', 570 p

2. Volosovych, S. (2011), «Rozvytok infrastruktury rynku kredytnogo strahuvannja v Ukrai'ni», Visnyk KNTEU, No. 5, pp. 36-43.

3. Prihno, I.M. (2015), «Suchasni tendencii' rozvytku kredytnogo strahuvannja v Ukrai'ni», Visnyk Shidnojevropejs'kogo universytetu ekonomiky i menedzhmentu, No. 2 (19), pp. 153-161.

4. Pahomova, I.G. (2017), «Ocinka rynku strahuvannja kredytnyh ryzykiv v Ukrai'ni», Efektyvna ekonomika, No. 6, [Online], available at: http://www.economy.nayka.com.ua/?op=1\&z=5635

5. Shapoval, O.A. (2017), Upravlinnja ryzykamy bankivs'kogo spozhyvchogo kredytuvannja, Abstract of Diss. of. k.e.n., spec. 08.00.08, KNTEU, Kyi'v. 261 p., [Online], available at: https://knute.edu.ua

6. Shvec', O.V. (2017), Kontrol' ta sposoby minimizacii' kredytnogo ryzyku banku, Abstract of Diss. of. k.e.n., spec. 08.00.08, DVNZ «Universytet bankivs'koi' spravy», Kyi'v, 211 p., [Online], available at: http://ubs.edu.ua/images/PDF/shvetsdiser.pdf

7. Poljezhajeva, S. (2015), «Neobhidnist' strahuvannja kredytnyh ryzykiv dlja bankiv», Rynok cinnyh paperiv Ukrai'ny, No. $1-2$, pp 119-124.

8. Pro strahuvannja (1996), Zakon Ukrai'ny, vid 07.03, No. 85/96-VR, [Online], available at: https://zakon.rada.gov.ua/laws/show/85/96-vr/print

9. Cyvil'nyj kodeks Ukrai'ny, [Online], available at: https://zakon.rada.gov.ua/laws/show/435-15

10. Prymostka, L.O. (2009), Finansovyj menedzhment u banku, navch. posib., KNEU, Kyi'v, 280 p.

11. Novi vektory rozvytku strahovogo rynku Ukrai'ny, monografija (2012), in Koz'menko, O.V. (ed.), Sumy, 316 p.

12. Alyev, B.H. (2011), Strahovanye, uchebnyk, Moskva, 415 p.

13. Jevrointegracijni aspekty rozvytku rynkiv finansovyh poslug, monografija (2018), in Vnukova, N.M. (ed.), Harkiv, 178 p.

14. Pravyla dobrovil'nogo strahuvannja kredytiv ( $v$ tomu chysli vidpovidal'nist' pozychal'nyka za nepogashennja kredytu), SK «ASKA», [Online], available at: https://aska.ua/assets/files/pravila-dobrovilnogo-strahuvannya-kreditiv-v-tomu-chislividpovidalnist-pozichalnika-za-nepogashennya-kreditu-nova-redakciya.pdf

15. Pravyla dobrovil'nogo strahuvannja kredytiv ( $v$ tomu chysli vidpovidal'nist' pozychal'nyka za nepogashennja kredytu), SK «Arsenal-Dnepr», [Online], available at: https://arsenal-ic.ua/uploads/0/1040.pdf

Катранжи Леонід Леонідович - кандидат економічних наук, доцент, доцент кафедри управління i фінансово-економічної безпеки ДВНЗ «Донецький національний технічний університет».

Наукові інтереси:

- формування і використання банківського капіталу;

- банківське регулювання і нагляд, управління ризиками;

- функціонування і розвиток публічних фінансів;

- інвестиційна діяльність на фінансовому ринку.

https://orcid.org/0000-0002-1723-3498.

E-mail: leonid.katranzhy@donntu.edu.ua.

Марина Анна Сергіївна, кандидат економічних наук, доцент, доцент кафедри управління і фінансовоекономічної безпеки ДВНЗ «Донецький національний технічний університет».

Наукові інтереси:

- механізми забезпечення фінансово-економічної безпеки на макро- та мікрорівнях;

- розвиток фінансового сектору країни та його складових елементів.

https://orcid.org/0000-0001-5634-9402.

E-mail: anna.maryna@donntu.edu.ua. 